\title{
Anomalous hydrographic conditions off the northwestern coast of the Baja California Peninsula during 2013-2016
}

\section{Condiciones hidrográficas anómalas frente a la costa noroeste de la península de Baja California durante 2013-2016}

\author{
Reginaldo Durazo ${ }^{1 *}$, Rubén Castro ${ }^{1}$, Luis E Miranda ${ }^{2}$, Francisco Delgadillo-Hinojosa ${ }^{3}$, \\ Adán Mejía-Trejo ${ }^{3}$ \\ ${ }^{1}$ Facultad de Ciencias Marinas, Universidad Autónoma de Baja California Carretera Tijuana-Ensenada, \\ no. 3917, Zona Playitas, Ensenada, Baja California, México. \\ ${ }^{2}$ División de Oceanología, Centro de Investigación Científica y de Educación Superior de Ensenada, Carretera \\ Tijuana-Ensenada, no. 3918, Zona Playitas, Ensenada, Baja California, México. \\ ${ }^{3}$ Instituto de Investigaciones Oceanológicas, Universidad Autónoma de Baja California, Carretera Tijuana- \\ Ensenada, no. 3917, Zona Playitas, Ensenada, Baja California, México.
}

* Corresponding author. E-mail: rdurazo@uabc.edu.mx

\begin{abstract}
A succession of interannual warm events occurred in the Pacific during the 2013-2016 period, when positive thermal anomalies were detected. A broad region with abnormally warm waters in the northeastern Pacific Ocean was observed in 2013, which by 2015 had reached waters off Baja California (Mexico). In addition to the ongoing warming effect, early evidence of an El Niño event was detected in 2015. This paper analyzes hydrographic data measured at Todos Santos Bay and environs, as well as satellite-derived sea-level data, to characterize changes in the hydrographic conditions during the $2013-2016$ period. The highest positive temperature anomalies $\left(\sim 5{ }^{\circ} \mathrm{C}\right)$ were observed in September 2015, with a steep decline to neutral conditions in spring 2016. Records for the bay showed slight variations in hydrographic conditions during spring, highlighting the importance of local over remote forcings during this time of year. In autumn, by contrast, interannual signals prevailed over local processes. Satellite-derived sea-level data revealed an alongshore propagation of remote signals, identified as shallow coastal poleward flows.
\end{abstract}

Key words: hydrography, interannual variability, IMECOCAL program, surface countercurrent.

RESUMEN. En el periodo 2013-2016 se presentó en el Pacífico una sucesión de eventos cálidos de escala interanual, durante los cuales se manifestaron anomalías térmicas positivas. Durante 2013 se observó una región muy extensa de aguas anómalamente cálidas, la cual se formó en el Pacífico nororiental y, para 2015, se extendió hacia aguas frente a Baja California (México). También en 2015, además del efecto de calentamiento ya existente, se registraron las primeras evidencias de un evento El Niño. En este trabajo se analizan los datos hidrográficos medidos en la bahía Todos Santos y sus alrededores, así como datos satelitales del nivel del mar, para caracterizar los cambios en las condiciones hidrográficas durante el periodo 2013-2016. Las observaciones mostraron las máximas anomalías positivas de temperatura $\left(\sim 5^{\circ} \mathrm{C}\right)$ durante septiembre de 2015 y un rápido decaimiento hacia condiciones neutras en la primavera de 2016. Los registros para la bahía mostraron cambios leves en las condiciones hidrográficas durante la primavera, lo cual evidenció la importancia de los forzamientos locales sobre los forzamientos remotos en esa época del año. En contraste, en otoño las señales interanuales dominaron sobre los procesos locales. El análisis de datos de altimetría sugirió una conectividad entre el norte y sur frente a la península a través de la propagación de señales, identificadas como un flujo costero superficial hacia el polo.

Palabras clave: hidrografía, variabilidad interanual, programa IMECOCAL, contracorriente superficial.

\section{INTRODUCTION}

A large portion of the variability that occurs in the transition zone of the California Current System is associated with interannual events. This transition zone is defined as the area off the Baja California Peninsula where the relatively cold and low-salinity water of the California Current meets warmer and more saline tropical and subtropical waters. Interannual variability affects the physical properties and ecosystem processes in the area. During warm events (e.g.,

\section{INTRODUCCIÓN}

Gran parte de la variabilidad hidrográfica que ocurre en la zona de transición del Sistema de la Corriente de California está asociada con eventos de escala interanual. Esta zona de transición está definida como el área frente a la península de Baja California donde confluyen el agua relativamente fría y de baja salinidad de la corriente de California y las aguas más cálidas y salinas de origen tropical y subtropical. La variabilidad interanual produce cambios en las propiedades físicas y 
El Niño), the positive temperature anomalies detected in the equatorial region were also detected off the peninsula. The connectivity results from the modification of local atmospheric processes due to atmospheric teleconnections and the propagation of remote signals across the ocean (Frischknecht et al. 2017). In addition to positive temperature anomalies, the responses of the ocean to warm events in the transition zone include increased salinity, deepening of the thermocline and nutricline (Durazo and Baumgartner 2002, Zaba and Rudnick 2016), decreased chlorophyll concentrations (Espinosa-Carreon et al. 2004), and regional changes in species composition of marine zooplankton (Cavole et al. 2016). Some of these changes are related to the reduction of heat exchange between the ocean and the atmosphere (Bond et al. 2015, Jacox et al. 2016) or to the weakening of alongshore winds that favors the advection of tropical and subtropical waters from the south, off the Baja California peninsula, due to a poleward coastal flow (Durazo 2009).

During cold interannual events (e.g., La Niña) oceanic conditions generally contrast those observed during warm events. When a La Niña event occurs, the eastern Pacific high atmospheric pressure center intensifies, leading to stronger alongshore winds that promote coastal upwelling. As a result, offshore Ekman transport increases, upwelling of nutrientrich subsurface waters intensifies, and chlorophyll concentration increases (Espinosa-Carreon et al. 2004, Gaxiola-Castro et al. 2008). During La Niña, water temperature in the region is lower than average and salinity is higher due to the higher input of more saline subsurface waters $(\sim 50-70 \mathrm{~m})$. However, a more intense transport of subarctic waters also takes place, contributing water of lower salinity that predominates over the newly upwelled water (Bjorkstedt et al. 2011). In addition, zooplankton communities are dominated by temperate species during La Niña (Linacre 2004).

An unusual event that occurred recently (2013-2016) was the anomalous rise in temperature in the upper layer of the northeast Pacific caused by a decreased cooling of the ocean surface and weaker winds (Bond et al. 2015, Gentemann et al. 2017). These warmer temperatures were first detected in the subpolar coastal region, and within a few months spread down to the region off California and Baja California. Due to the rapid spatial expansion and the dimensions of the warm water mass, this phenomenon was named "The Blob", after a science fiction movie. By mid-2015, the thermal anomalies stretched across a broad area in the northeastern Pacific, and early signs of an El Niño event were observed in the California Current System in August 2015 (Cavole et al. 2016). Due to the transition from the preexisting warm conditions associated with the Blob, El Niño was expected to be a major event and was thus described as "El Niño Godzilla," after another science fiction movie. This unusual coincidence of the 2 warm events raised considerable uncertainty about the potential effects on climate at a regional scale.

The anomalous conditions accompanying the successive warm events (the Blob and El Niño Godzilla) resulted in los procesos del ecosistema. Durante eventos cálidos (e.g., El Niño), las anomalías positivas de temperatura que se registran en la región ecuatorial se detectan también en la región frente a la península. La conectividad se da por la modificación de procesos atmosféricos locales debido a las teleconexiones atmosféricas, y por la propagación de señales remotas a través del océano (Frischknecht et al. 2017). Además de las anomalías positivas de temperatura, las respuestas del océano a los eventos cálidos en la región de transición incluyen el aumento en la salinidad, la profundización de la termoclina y nutriclina (Durazo y Baumgartner 2002, Zaba y Rudnick 2016), la reducción en la concentración de clorofilas (Espinosa-Carreon et al. 2004) y los cambios regionales en las especies componentes del zooplancton marino (Cavole et al. 2016). Algunos de estos cambios están relacionados con la reducción del flujo de calor desde el océano hacia la atmósfera (Bond et al. 2015, Jacox et al. 2016) o con el debilitamiento de los vientos a lo largo de la costa que favorece la advección de aguas tropicales y subtropicales desde la región frente al sur de la península debido a la presencia de un flujo costero hacia el polo (Durazo 2009).

Durante eventos interanuales fríos (e.g., La Niña), las condiciones observadas son generalmente contrarias a las observadas durante eventos cálidos. En un evento La Niña, el centro de alta presión atmosférico del Pacífico oriental se intensifica, con lo que también se intensifican los vientos a lo largo de la costa que favorecen las surgencias costeras. Ocurre, por lo tanto, un incremento en el transporte de Ekman hacia afuera de la costa, un mayor afloramiento de aguas subsuperficiales ricas en nutrientes y un incremento en la concentración de clorofila (Espinosa-Carreon et al. 2004, Gaxiola-Castro et al. 2008). Durante La Niña, se registran en la región temperaturas más frías que la media climatológica y salinidades más altas debido al mayor aporte de aguas subsuperficiales $(\sim 50-70 \mathrm{~m})$ de mayor salinidad. Sin embargo, también suele ocurrir un transporte más intenso de aguas del subártico, que son de menor salinidad y dominan sobre aquellas recién emergidas por la surgencia costera (Bjorkstedt et al. 2011). Además, durante La Niña, las comunidades de zooplancton se caracterizan por una dominancia de especies templadas (Linacre 2004).

Un evento inusual que ocurrió recientemente (2013-2016) fue el incremento anómalo de temperatura en la capa superior del océano en el Pacífico nororiental, causado por una disminución del enfriamiento superficial del océano y por un debilitamiento de los vientos (Bond et al. 2015, Gentemann et al. 2017). Dicho incremento de temperatura se observó primeramente en la región costera subpolar, y en pocos meses se extendió hacia la región frente a California y Baja California. Debido al rápido incremento en su distribución espacial y a sus dimensiones, esta masa de agua cálida recibió el nombre de "The Blob", en alusión a una película de ciencia ficción; en este trabajo utilizamos su equivalente en español como "La Mancha". Hacia mediados de 2015, las anomalías térmicas estaban bastante extendidas en el Pacífico 
major changes in the hydrographic and trophic conditions in the California Current System (Leising et al. 2015, McClatchie et al. 2016). Although some of these effects have already been described in the literature (Zaba and Rudnick 2016, Gómez-Ocampo et al. 2017), a detailed description of changes that occurred at a regional level is still missing. In this paper, the hydrographic conditions off the northwestern coast of the Baja California peninsula are analyzed, particularly at Todos Santos Bay and nearby waters, to characterize the response of the region to such events. In addition, evidence from satellite data was analyzed to explore the effect of remote forcings on local coastal waters.

\section{MATERIALS AND METHODS}

As part of the field surveys organized for students by the Faculty of Marine Sciences at the Autonomous University of Baja California (UABC, for its acronym in Spanish), 3-day oceanographic cruises are conducted on board Mexican Navy ships. Two cruises are conducted per year, typically in March and September (spring and fall). Onboard activities include performing routine vertical casts to measure conductivity, temperature, and hydrostatic pressure along 3 transects from the inner part of the bay toward the California Current System domain (Fig. 1a). Between September 2010 and March 2013, measurements were made with a factory-calibrated Seabird SBE19Plus v2 CTD from the surface down to a few meters above the sea floor. A handheld CastAway-CTD instrument was used between March 2014 and April 2017 to take readings between the surface and $\sim 80$ m depth. Typically, the Seabird CTD records temperature, conductivity, and pressure with accuracy of $\pm 0.005{ }^{\circ} \mathrm{C}, \pm 0.0005 \mathrm{~S} \cdot \mathrm{m}^{-1}$, and $\pm 0.1 \%$ in the $0-600 \mathrm{~m}$ scale, respectively. The CastAway instrument measures these same parameters with $\pm 0.05{ }^{\circ} \mathrm{C}$, $\pm 0.05 \mathrm{~S} \cdot \mathrm{m}^{-1}$, and $\pm 0.25 \%$ accuracy, respectively. The data collected with the latter instrument showed discrepancies $\left(0.2 \mathrm{~g} \cdot \mathrm{kg}^{-1}\right)$ in salinity values, so correction was done by comparing data with measurements obtained from water samples that were collected in bottles and analyzed at the laboratory with a Guildline Autosal $8400 \mathrm{~B}$ salinometer $( \pm 0.002$ accuracy). For this work, we analyzed data collected from a total of 260 vertical casts carried out during 12 oceanographic cruises.

In addition to data gathered from the oceanographic cruises, data recorded off the bay by the Investigaciones Mexicanas de la Corriente de California program (Mexican Research Program of the California Current; IMECOCAL, for its acronym in Spanish) were also used. The data considered for this work corresponded to information obtained from 55 vertical casts performed at 7 hydrographic stations along line 100 of the program (Fig. 1b). In total, data from 7 cruises were analyzed: January and April 2013 (1301 and 1304), July and October 2014 (1407 and 1410), October 2015 (1510), and January and April 2016 (1601 and 1604). These readings were recorded on board the Francisco de Ulloa and Alpha nororiental, y las primeras indicaciones de un evento El Niño se observaron en agosto de 2015 dentro del Sistema de la Corriente de California (Cavole et al. 2016). Debido a la transición de las condiciones cálidas preexistentes por la presencia de La Mancha, se pronosticó que dicho evento El Niño sería un evento mayúsculo, razón por la cual recibió el nombre de "El Niño Godzila", en alusión a otra película de ciencia ficción. Esta cadena inusual de 2 eventos cálidos propició mucha incertidumbre acerca de cuáles serían los efectos en el clima regional.

Las condiciones anómalas durante la sucesión de los eventos La Mancha y El Niño Godzila originaron cambios importantes en las condiciones hidrográficas y tróficas del Sistema de la Corriente de California (Leising et al. 2015, McClatchie et al. 2016). A pesar de que algunos de estos efectos han sido descritos en la literatura (Zaba y Rudnick 2016, Gómez-Ocampo et al. 2017), aún se requiere una descripción detallada de los cambios que ocurrieron a nivel regional. En este trabajo, se analizan las condiciones hidrográficas en la región frente al noroeste de la península de Baja California, con énfasis en la bahía Todos Santos y sus alrededores, para caracterizar la respuesta de la región ante dichos eventos cálidos. Así mismo, se analizan las evidencias de datos satelitales para dilucidar sobre la respuesta local del océano costero ante forzamientos remotos.

\section{MATERIALES Y MÉTODOS}

Como parte de las actividades de prácticas estudiantiles que cada semestre lleva a cabo la Facultad de Ciencias Marinas de la Universidad Autónoma de Baja California (UABC), se realizan cruceros oceanográficos de corta duración (3 días) a bordo de barcos de la Armada de México. Usualmente, se efectúan 2 campañas por año, típicamente en marzo y septiembre (condiciones de primavera y otoño). Como parte de las actividades, se mide de forma rutinaria la conductividad, temperatura y presión hidrostática mediante hidrocalas verticales a lo largo de 3 transectos desde el interior de la bahía hacia el dominio del Sistema de la Corriente de California (Fig. 1a). Entre septiembre de 2010 y marzo de 2013, las mediciones se realizaron con un CTD Seabird SBE19Plus v2 con calibración de fábrica, desde la superficie hasta unos metros sobre el fondo. Entre marzo de 2014 y abril de 2017, se utilizó un perfilador CTD CastAway portátil para realizar las mediciones entre la superficie y los $\sim 80 \mathrm{~m}$ de profundidad. Típicamente, el CTD Seabird mide temperatura, conductividad y presión con una exactitud de $\pm 0.005^{\circ} \mathrm{C}$, $\pm 0.0005 \mathrm{~S} \cdot \mathrm{m}^{-1} \mathrm{y} \pm 0.1 \%$ de la escala de $0-600 \mathrm{~m}$, respectivamente. El CTD CastAway mide los mismos parámetros con exactitud de $\pm 0.05{ }^{\circ} \mathrm{C}, \pm 0.05 \mathrm{~S} \cdot \mathrm{m}^{-1}$ y $\pm 0.25 \%$, respectivamente. Los datos recolectados por este instrumento mostraron un ligero sesgo $\left(0.2 \mathrm{~g} \cdot \mathrm{kg}^{-1}\right)$ en los valores de salinidad respecto a las mediciones obtenidas de muestras recolectadas con botellas y analizadas en el laboratorio con un salinómetro Guildline Autosal 8400B que mide con exactitud de \pm 0.002 . 


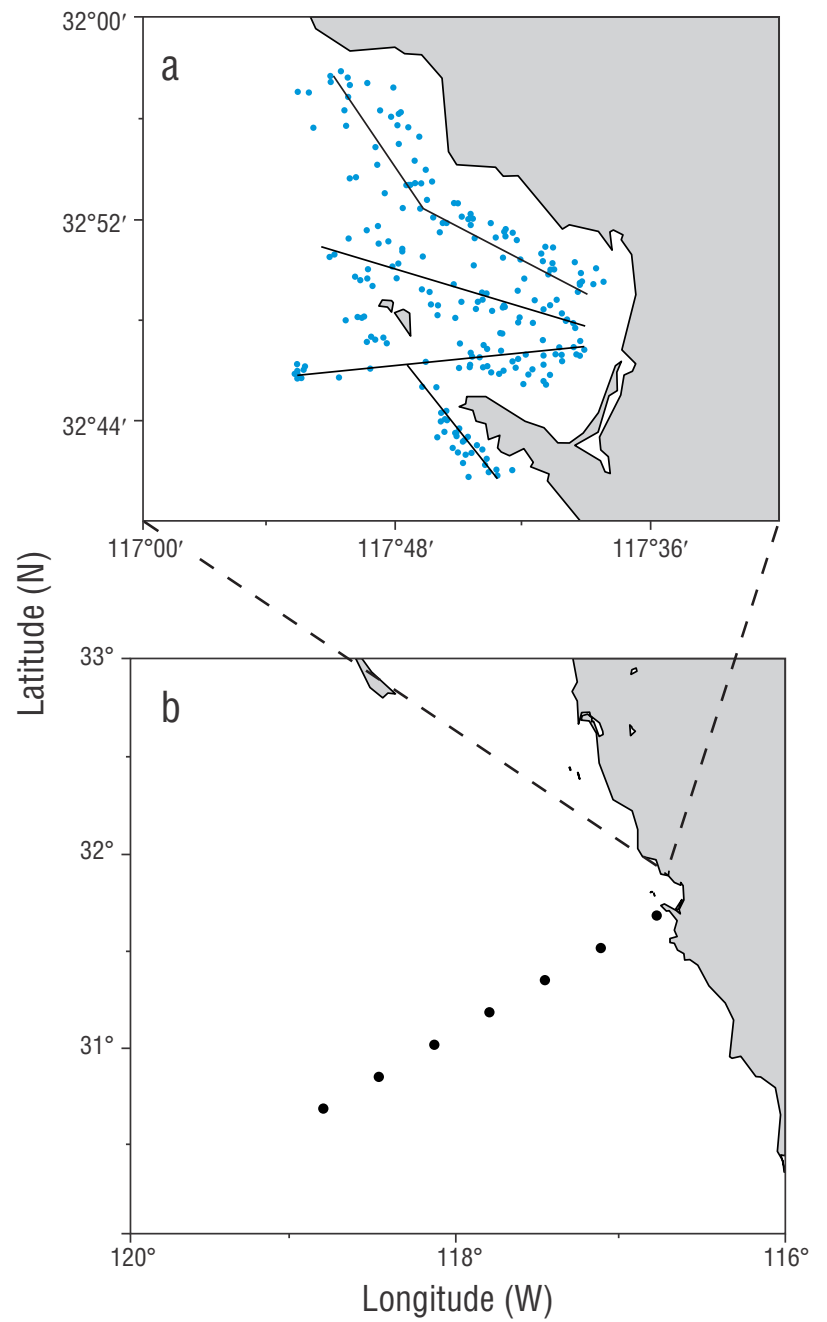

Figure 1. Map of the study area where CTD measurements were recorded: (a) location of the stations at Todos Santos Bay, Baja California (Mexico), occupied between 2010 and 2016, approximately defined by the 3 superimposed lines; (b) location of the hydrographic stations (filled circles) along line 100 of the IMECOCAL program.

Figura 1. Mapa del área de estudio donde se realizaron las observaciones con CTD: (a) ubicación de las estaciones (círculos azules) ocupadas entre 2010 y 2016, definidas de manera aproximada por las 3 líneas sobrepuestas, en bahía Todos Santos, Baja California (México); (b) ubicación de las estaciones hidrográficas (círculos negros) de la línea 100 del programa IMECOCAL.

Helix research vessels. A factory-calibrated Seabird 911Plus CTD was used in all cruises. In order to identify temperature and salinity anomalies along line 100, measured data were contrasted with the long-term (1997-2016) climatology obtained using a harmonic fit with the annual signal (Emery and Thomson 2001).

Analysis of in-situ data was supplemented by using daily sea level data obtained from satellite altimetry for the 1992-2016 period. The data corresponded to absolute
Los datos fueron corregidos para eliminar el sesgo. En total, se analizaron datos de 260 hidrocalas verticales realizadas en 12 campañas oceanográficas.

Adicional a los datos provenientes de los cruceros de prácticas, se utilizaron datos medidos afuera de la bahía por el programa de Investigaciones Mexicanas de la Corriente de California (IMECOCAL). Los datos considerados para este trabajo correspondieron a la información obtenida de 55 hidrocalas verticales realizadas en 7 estaciones hidrográficas de la línea 100 de dicho programa (Fig. 1b). En total se analizaron datos de 7 campañas: en enero y abril de 2013 (cruceros 1301 y 1304), julio y octubre de 2014 (cruceros 1407 y 1410), octubre de 2015 (crucero 1510) y enero y abril de 2016 (cruceros 1601 y 1604). Estas mediciones se realizaron a bordo de los buques de investigación Francisco de Ulloa y Alpha Helix. En todas las campañas se utilizó un CTD Seabird 911Plus con calibración de fábrica. Con el fin de obtener las anomalías de temperatura y salinidad en la línea 100 , los datos medidos se contrastaron con la climatología hidrográfica de largo periodo (1997-2016) obtenida mediante un ajuste armónico con la señal anual (Emery y Thomson 2001).

Para complementar el análisis de los datos in situ, se utilizaron datos diarios del nivel del mar obtenidos por altimetría satelital en el período 1992-2016. Los datos correspondieron a la altura dinámica absoluta proporcionados en una malla de $0.25^{\circ}(\sim 25 \mathrm{~km})$ de resolución espacial por el Copernicus Marine Environment Monitoring Service de la Comisión Europea (http://marine.copernicus.eu).

\section{RESUltadOS}

La variabilidad de las condiciones hidrográficas, tanto dentro de la bahía Todos Santos como a lo largo de la línea 100 de IMECOCAL, se ilustra como curvas promedio de las distribuciones de temperatura y salinidad (T-S) por crucero (Fig. 2). En la bahía Todos Santos, las condiciones hidrográficas durante las diferentes observaciones de marzo (Fig. 2a) mostraron una ligera variabilidad en la salinidad, pero homogeneidad en la temperatura, sin efectos notorios por eventos interanuales cálidos. La salinidad, que no necesariamente responde a eventos interanuales (Bjorkstedt et al. 2011), mostró una transición de salinidades promedio bajas $(<33.5)$ en la capa superficial $\left(\sigma_{\theta}<26 \mathrm{~kg} \cdot \mathrm{m}^{-3}\right)$ durante $2011 \mathrm{a}$ salinidades con valores de $\sim 33.7$ en 2014. Las bajas salinidades durante 2011 fueron aparentemente el resultado de la intensificación de la corriente de California, que acarreó un mayor volumen de agua con características del subártico (Bjorkstedt et al. 2011). Las mayores salinidades registradas durante 2014 aparentemente estuvieron relacionadas con $\mathrm{La}$ Mancha a través de un mayor transporte de aguas de origen sureño o a través de una modificación en las tasas de evaporación en la interfase aire-mar (Bond et al. 2015, Leising et al. 2015). El resto de los muestreos de marzo mostró curvas 
dynamic topography mapped on a grid with a $0.25^{\circ}(\sim 25 \mathrm{~km})$ spatial resolution from the Copernicus Marine Environment Monitoring Service of the European Commision (http:// marine.copernicus.eu).

\section{RESUlts}

Variability in hydrographic conditions, both in Todos Santos Bay and along IMECOCAL line 100, is depicted as average temperature-salinity (T-S) curves per cruise (Fig. 2). At Todos Santos Bay, hydrographic conditions in March (Fig. 2a) showed slight fluctuations in salinity but relatively constant temperatures, with no noticeable effects of warm interannual events. Salinity, which does not necessarily respond to interannual events (Bjorkstedt et al. 2011), showed a transition from low average salinity values $(<33.5)$ in the surface layer $\left(\sigma_{\theta}<26 \mathrm{~kg} \cdot \mathrm{m}^{-3}\right)$ during 2011 to $\sim 33.7$ in 2014. The low salinity values observed during 2011 apparently resulted from the intensification of the California Current, which carried a larger volume of subarctic water (Bjorkstedt et al. 2011). The higher salinity values recorded in 2014 were likely related to the Blob because of the increased transport of waters from the south or because of a change in the evaporation rates at the air-sea interface (Bond et al. 2015, Leising et al. 2015). The rest of the samples for March showed very similar average curves, including the data from 2015, when the Blob displayed its peak influence at the regional level.

Unlike the spring T-S curves, average curves for September show relatively homogeneous salinity (33.3-33.5) and relatively high temperature values in the upper layer (Fig. 2b). The average curves for September 2014 and September 2015 are worth noting, with average sea surface temperatures of up to 23 and $25^{\circ} \mathrm{C}$, respectively. Before the September 2014 cruise and after September 2015, the curves per cruise indicate that relatively normal conditions persisted, with maximum sea surface temperatures of $\sim 20{ }^{\circ} \mathrm{C}$. The extreme temperature values observed in 2014 and 2015 are a clear response to interannual events: the Blob in 2014 and El Niño in the second half of 2015.

The outside of Todos Santos Bay (line 100), which includes the California Current domain, also showed evidence of the alternation of events (Fig. 2c). The average T-S curves per cruise show salinity values below the climatological mean around the relative subsurface minimum located in the $\sigma_{\theta} \sim 25.0-25.4 \mathrm{~kg} \cdot \mathrm{m}^{-3}$ isopycnal range. At depths above and below this range, the curves show profiles very similar to the long-term mean (1998-2016). Exceptions were the curves for July 2014 (1407), October 2014 (1410), and October 2015 (1510), when mean sea surface temperature was higher than average. The observed maximum average temperatures were $\sim 20, \sim 21$ and $23^{\circ} \mathrm{C}$ for October 2014, July 2014, and September 2015, respectively.

The time evolution of temperature anomalies along line 100 showed conditions close to the climatological mean for promedio muy similares, incluso los datos de 2015 , cuando La Mancha mostró su máxima expresión a nivel regional.

A diferencia de las curvas T-S para la primavera, las curvas promedio para septiembre muestran salinidades relativamente uniformes (33.3-33.5) en la capa superior, pero temperaturas relativamente altas (Fig. 2b). Destacan las curvas promedio para septiembre de 2014 y de 2015 , cuando las temperaturas superficiales promedio alcanzaron hasta 23 y $25^{\circ} \mathrm{C}$, respectivamente. Previo y posterior a estos años, las curvas por crucero indican condiciones relativamente normales, con temperaturas superficiales máximas de $\sim 20^{\circ} \mathrm{C}$. Los valores extremos de temperatura observados en 2014 y 2015 son una clara respuesta a eventos interanuales: La Mancha en 2014 y El Niño en la segunda mitad de 2015.

La zona fuera de la bahía Todos Santos (línea 100), que incluye el dominio de la corriente de California, también mostró evidencia de la alternancia de eventos (Fig. 2c). Las curvas T-S promedio por crucero muestran condiciones de salinidades menores que la media climatológica alrededor del mínimo relativo subsuperficial localizado en el intervalo isopicnal de $\sigma_{\theta} \sim 25.0-25.4 \mathrm{~kg} \cdot \mathrm{m}^{-3}$. A profundidades superiores e inferiores a dicho intervalo, las curvas por crucero muestran perfiles muy similares al promedio de largo periodo de todos los datos (1998-2016). Las excepciones fueron las curvas para los cruceros de julio de 2014 (1407), octubre de 2014 (1410) y octubre de 2015 (1510), cuando la temperatura media de la capa superficial estuvo por encima de la norma. Las temperaturas promedio máximas observadas por crucero fueron de $\sim 20, \sim 21$ y $23{ }^{\circ} \mathrm{C}$ durante octubre de 2014 , julio de 2014 y septiembre de 2015 , respectivamente.

La evolución temporal de las anomalías de temperatura sobre la línea 100 mostró condiciones cercanas a la media climatológica durante 2013 (cruceros 1301 y 1304), con anomalías alrededor de cero en la parte superior de la columna de agua (0-300 m, Fig. 3). La pendiente positiva de la isopicna de $\sigma_{\theta}=25.2 \mathrm{~kg} \cdot \mathrm{m}^{-3}$ para ambos cruceros mostró condiciones de surgencia costera, que fueron más intensas durante abril. En el mismo mes, el efecto del afloramiento costero se vió reflejado en la pendiente positiva de la isopicna de $\sigma_{\theta}=$ $26.3 \mathrm{~kg} \cdot \mathrm{m}^{-3}$.Por otro lado, las anomalías de salinidad mostraron condiciones dentro de la norma, con anomalías ligeramente positivas $(\sim 0.2)$ en los primeros $50 \mathrm{~m}$ y negativas $(-0.1 \mathrm{a}-0.2)$ a mayor profundidad.

El efecto de los eventos cálidos fue perceptible en julio de 2014 (1407), cuando se observaron anomalías de temperatura positivas (hasta $3{ }^{\circ} \mathrm{C}$ ) confinadas en los primeros $50 \mathrm{~m}$ de profundidad cerca de la costa. La isopicna de $\sigma_{\theta}=$ $25.2 \mathrm{~kg} \cdot \mathrm{m}^{-3}$ tuvo una pendiente reducida, aunque positiva, en casi toda la sección. Entre los 50 y $200 \mathrm{~m}$ de profundidad, se observaron anomalías cercanas a cero, las cuales se volvieron de nuevo positivas a mayor profundidad o cerca de la costa donde fluye el núcleo de la contracorriente subsuperficial (Durazo 2015), como lo indica la pendiente negativa hacia la costa de la superficie de $\sigma_{\theta}=26.3 \mathrm{~kg} \cdot \mathrm{m}^{-3}$. En general, la 

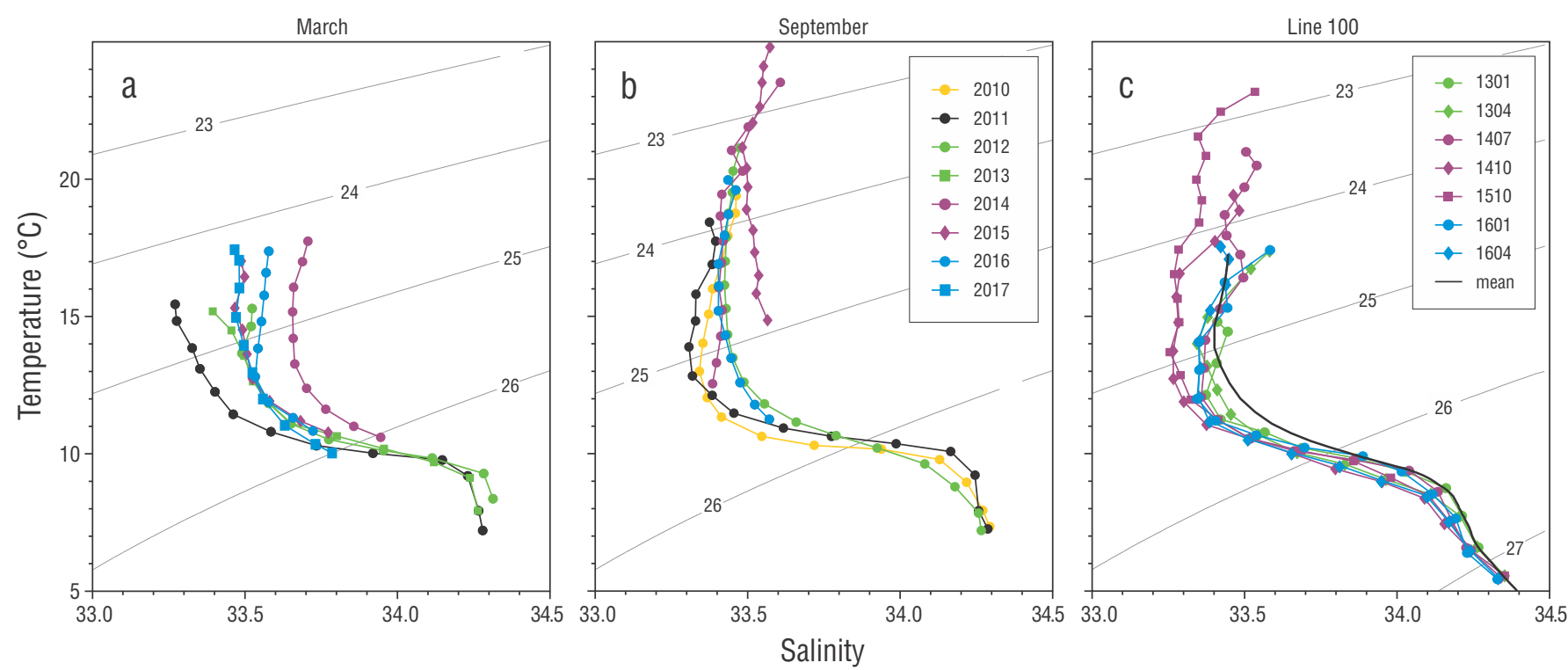

Figure 2. Average temperature-salinity curves for each survey conducted at Todos Santos Bay in March (a) and September (b) from 2010 to 2017, and average curves for each oceanographic cruise conducted along IMECOCAL line 100 (c). The black line in (c) depicts the long-term mean obtained from data recorded by the program between 1998 and 2016 . Contours indicate density anomaly $\left(\mathrm{kg} \cdot \mathrm{m}^{-3}\right)$ relative to the surface.

Figura 2. Curvas de temperatura y salinidad promedio para cada una de las campañas realizadas en la bahía Todos Santos en marzo (a) y septiembre (b) de 2010 a 2017; Curvas promedio para cada una de las campañas realizadas en la línea 100 del programa IMECOCAL (c). La línea negra en (c) representa el promedio de todos los datos obtenidos por el programa entre 1998 y 2016. Los contornos indican la anomalía de densidad $\left(\mathrm{kg} \cdot \mathrm{m}^{-3}\right)$ con referencia a la superficie.

2013 (cruises 1301 and 1304), with anomalies around zero in the upper layer of the water column $(0-300 \mathrm{~m}$, Fig. 3). The positive slope of the $\sigma_{\theta}=25.2 \mathrm{~kg} \cdot \mathrm{m}^{-3}$ isopycnal in both cruises revealed coastal upwelling, which was more intense in April. In this same month, the effect of coastal upwelling is reflected in the positive slope of the $\sigma_{\theta}=26.3 \mathrm{~kg} \cdot \mathrm{m}^{-3}$ isopycnal. Similarly, salinity anomalies were within the normal range, with slightly positive anomalies $(\sim 0.2)$ in the first $50 \mathrm{~m}$ and negative anomalies ( -0.1 to -0.2$)$ at greater depths.

The effect of warm events was evident in July 2014 (1407), with positive temperature anomalies (up to $3{ }^{\circ} \mathrm{C}$ ) in the upper $50 \mathrm{~m}$ of the water column close to the coast. The $\sigma_{\theta}=25.2 \mathrm{~kg} \cdot \mathrm{m}^{-3}$ isopycnal had a small positive slope throughout virtually the entire section. Anomalies were close to zero between 50 and $200 \mathrm{~m}$ depth but became positive again at greater depths or near the coast where the core of the California Undercurrent flows (Durazo 2015), as indicated by the negative slope of the $\sigma_{\theta}=26.3 \mathrm{~kg} \cdot \mathrm{m}^{-3}$ surface toward the coast. In general, the distribution of positive salinity anomalies during this cruise was similar to that of the positive temperature anomalies, with positive salinity anomalies at the same depths where temperature was higher than average.

The effects of the Blob and El Niño were clearly visible in the temperature and salinity anomaly sections for October 2014 and 2015 (cruises 1410 and 1510, respectively) and distribución de las anomalías positivas de salinidad durante este crucero fue muy similar a la de las anomalías positivas de temperatura; las anomalías de salinidad fueron positivas a las mismas profundidades donde la temperatura fue más alta que la media climatológica.

Los efectos de La Mancha y El Niño fueron claramente perceptibles en las secciones de anomalías de temperatura y salinidad calculadas para octubre de 2014 y 2015 (cruceros 1410 y 1510 , respectivamente) y enero de 2016 (crucero 1601) (Fig. 3). Durante el crucero 1410, los efectos del calentamiento fueron evidentes en el incremento de profundidad $(80-90 \mathrm{~m})$ y la pendiente nula de la superficie isopicnal de $\sigma_{\theta}=25.2 \mathrm{~kg} \cdot \mathrm{m}^{-3}$, así como en el incremento de la cobertura espacial (casi toda la sección) y la magnitud de las anomalías de temperatura (hasta $4{ }^{\circ} \mathrm{C}$ ). Para la salinidad, las anomalías ligeramente positivas se mantuvieron en la capa superficial $(0-50 \mathrm{~m})$, y las anomalías negativas se mantuvieron entre 50 y $300 \mathrm{~m}$ de profundidad entre los primeros $200 \mathrm{~km}$ desde la costa. Estas anomalías negativas aparentemente estuvieron relacionadas con el hundimiento de la corriente de California, como lo sugiere la posición vertical de la isopicna de $\sigma_{\theta}=$ $25.2 \mathrm{~kg} \cdot \mathrm{m}^{-3}$. Para octubre de 2015 (crucero 1510), la misma isopicna que delimita la corriente de California se mantuvo con pendiente nula y se hundió aún más (hasta $100 \mathrm{~m}$ ) en relación con las observaciones para los cruceros previos, con anomalías positivas de temperatura (máximos mayores que 

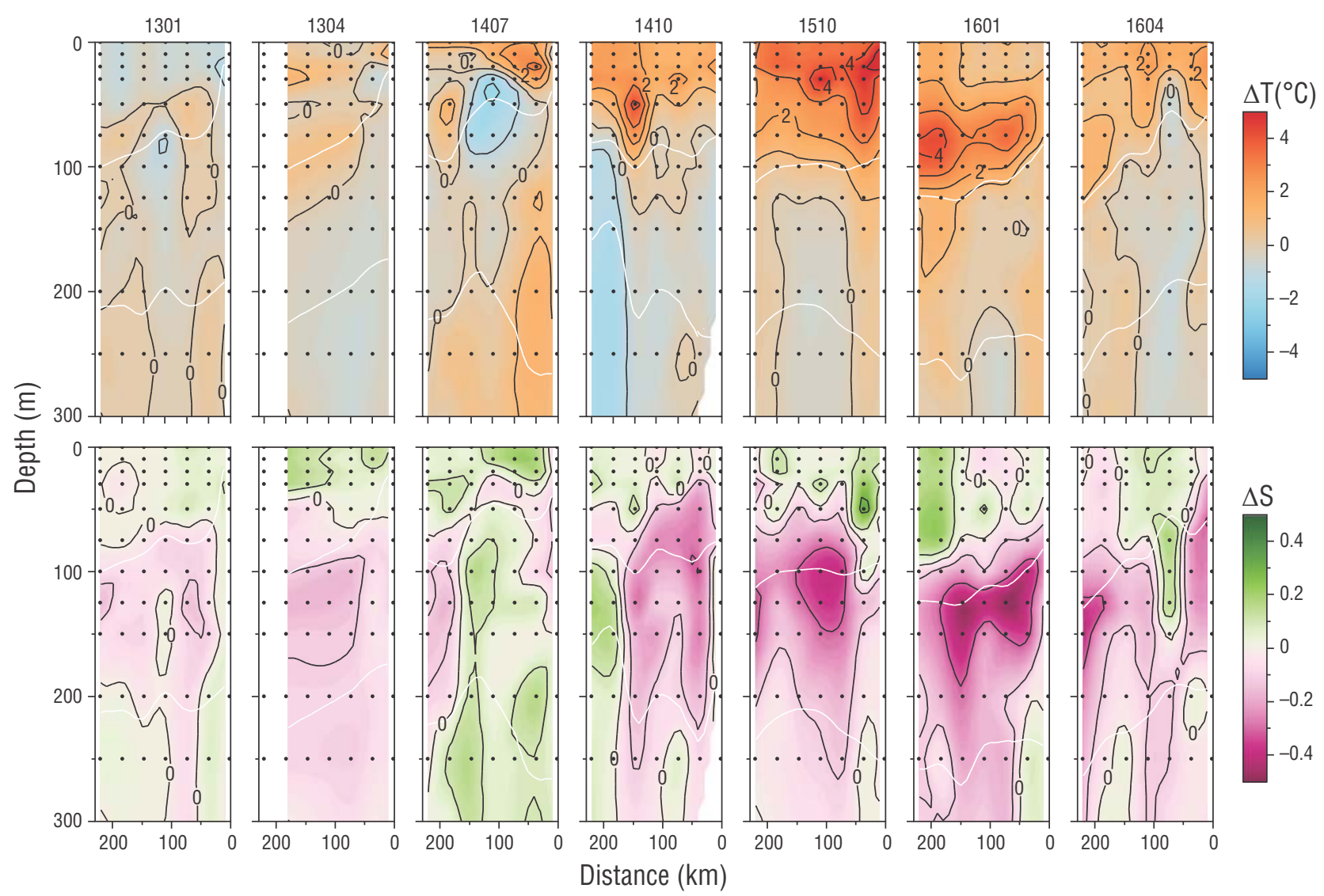

Figure 3. Temperature $\left({ }^{\circ} \mathrm{C}\right.$, above) and salinity (below) anomalies calculated for each oceanographic cruise conducted along IMECOCAL line 100 between 2013 and 2016. White contours represent the isopycnal surfaces of $\sigma_{\theta}=25.2 \mathrm{~kg} \cdot \mathrm{m}^{-3}$ and $\sigma_{\theta}=26.3 \mathrm{~kg} \cdot \mathrm{m}^{-3}$, corresponding to the upper limit of the California Current core and the location of California Undercurrent core, respectively. The contour intervals for temperature and salinity are $1{ }^{\circ} \mathrm{C}$ and 0.2 , respectively. Distance is relative to the station nearest to the coast. Dots indicate standard depths at each station.

Figura 3. Anomalías de temperatura $\left({ }^{\circ} \mathrm{C}\right.$, arriba) y salinidad (abajo) calculadas para cada una de las campañas (números en eje superior) realizadas a lo largo de la línea 100 del programa IMECOCAL entre 2013 y 2016. Los contornos en blanco representan las superficies isopícnicas de $\sigma_{\theta}=25.2 \mathrm{~kg} \cdot \mathrm{m}^{-3} \mathrm{y} \sigma_{\theta}=26.3 \mathrm{~kg} \cdot \mathrm{m}^{-3}$, que corresponden al límite superior del núcleo de la corriente de California y a la posición del núcleo de la contracorriente subsuperficial, respectivamente. Los intervalos de contorno para la temperatura y salinidad son de $1{ }^{\circ} \mathrm{C}$ y 0.2 , respectivamente. La distancia está referida a la primera estación cercana a la costa. Los puntos indican profundidades estándar en cada una de las estaciones.

January 2016 (1601) (Fig. 3). During cruise 1410, the effects of warming were evident at greater depths $(80-90 \mathrm{~m})$ and in the null slope of the $\sigma_{\theta}=25.2 \mathrm{~kg} \cdot \mathrm{m}^{-3}$ isopycnal surface, as well as in the increase in spatial coverage (almost the entire section) and magnitude of temperature anomalies (up to $4{ }^{\circ} \mathrm{C}$ ). In the case of salinity, slightly positive anomalies remained within the surface layer $(0-50 \mathrm{~m})$, while negative anomalies occurred between 50 and $300 \mathrm{~m}$ depth within the first $200 \mathrm{~km}$ off the coast. These negative anomalies were apparently related to the deepening of the California Current, as suggested by the vertical position of the $\sigma_{\theta}=25.2 \mathrm{~kg} \cdot \mathrm{m}^{-3}$ isopycnal. For October 2015 (cruise 1510), the same isopycnal that borders the California Current maintained a zero slope and sank even deeper (up to $100 \mathrm{~m}$ ) relative to the observations from previous cruises, with positive temperature anomalies (maxima greater than $5{ }^{\circ} \mathrm{C}$ ) across virtually
$5{ }^{\circ} \mathrm{C}$ ) que cubrieron casi toda la capa superficial entre 0 y $300 \mathrm{~m}$ de profundidad. La isopicna de $\sigma_{\theta}=26.3 \mathrm{~kg} \cdot \mathrm{m}^{-3}$ también alcanzó mayores profundidades, con una pendiente negativa cercana a la costa que indica el flujo hacia el polo de la contracorriente subsuperficial. La salinidad mostró la misma distribución de anomalías negativas que la observada para los datos del crucero 1410 del año anterior, aunque con magnitudes aún mayores $(>0.4)$ entre 100 y $125 \mathrm{~m}$ de profundidad, desde la costa hasta aproximadamente $250 \mathrm{~km}$ mar adentro. Los campos de anomalías y distribución de isopicnas para octubre de 2015 se mantuvieron sin cambio hasta el crucero de enero de 2016. En esta última fecha, el máximo de anomalías de temperatura fue similar al registrado para el crucero previo, aunque localizado subsuperficialmente entre los 50 y $70 \mathrm{~m}$ de profundidad. Las correspondientes superficies isopicnales se hundieron aún más, hasta 125 y $225 \mathrm{~m}$ de 
the entire surface layer between 0 and $300 \mathrm{~m}$ depth. The $\sigma_{\theta}=$ $26.3 \mathrm{~kg} \cdot \mathrm{m}^{-3}$ isopycnal also reached greater depths, with a negative slope close to the coast indicating a poleward flow of the California Undercurrent. Salinity showed the same distribution of negative anomalies as that observed for data from cruise 1410 the previous year, but with even greater magnitudes $(>0.4)$ between 100 and $125 \mathrm{~m}$ depth, from the coast to approximately $250 \mathrm{~km}$ offshore. The anomaly fields and distribution of isopycnals for October 2015 remained the same for January 2016. On the latter date, the maximum temperature anomaly was similar to that observed in October 2015 , though it was located below the surface between 50 and $70 \mathrm{~m}$ depth. The corresponding isopycnals sank even more, down to 125 and $225 \mathrm{~m}$ depth for $\sigma_{\theta}=25.2 \mathrm{~kg} \cdot \mathrm{m}^{-3}$ and $\sigma_{\theta}=26.3 \mathrm{~kg} \cdot \mathrm{m}^{-3}$, respectively. This deepening of isopycnals was also evident in the position of the maximum salinity anomaly below $100 \mathrm{~m}$ resulting from the deepening of the California Current core.

The reappearance of normal conditions was observed in the smaller temperature anomalies in April 2016 (Fig. 3, cruise 1604), with a maximum of approximately $2{ }^{\circ} \mathrm{C}$. Although the system did not attain full recovery on this date compared with April 2013, isopycnals showed a shallower position and a positive slope. As for salinity, values were either within the normal range or slightly positive in the first $100 \mathrm{~m}$, with persistent negative anomalies (although of lesser magnitude) below $100 \mathrm{~m}$ depth.

\section{DISCUSSION}

This study showed the effects of the sequence of events, from the Blob to El Niño, on the hydrographic features off the northwestern coast of the Baja California peninsula, Mexico, using data collected during oceanographic cruises conducted at Todos Santos Bay and along line 100 of the IMECOCAL program. In the bay, data revealed differences in hydrography between March and September, in response to interannual events. In March, the average T-S curve, with lower salinity values, corresponded to data obtained under a cold La Niña event in 2011. The lower salinity values were likely associated with an increased transport of subarctic water from the California Current, as documented for other regions of the California Current System (Bjorkstedt et al. 2011). Peak salinity values were associated with the anomalous warming due to the Blob. The factors that may have led to increased salinity values during this event are the anomalous advection of tropical and subtropical waters associated with coastal poleward flows, and the higher evaporation rate at the interface. Although there are insufficient elements to assess the relative importance of the latter, previous studies (e.g., Zaba and Rudnick 2016) showed that at the regional level, within the California Current System, salinity increase was partly due to the changes in air-sea exchange rates and wind weakening. The present study assessed the potential existence of coastal poleward flows based on sea-level data. profundidad para $\sigma_{\theta}=25.2 \mathrm{~kg} \cdot \mathrm{m}^{-3} \mathrm{y} \sigma_{\theta}=26.3 \mathrm{~kg} \cdot \mathrm{m}^{-3}$, respectivamente. Este hundimiento de isopicnas también se hizo evidente en la posición del máximo de la anomalía de salinidad por debajo de los $100 \mathrm{~m}$, producto del hundimiento del núcleo de la corriente de California.

El retorno hacia condiciones normales se vio reflejado en la disminución de la magnitud de las anomalías de temperatura en abril de 2016 (Fig. 3, crucero 1604), cuando el máximo fue de aproximadamente $2{ }^{\circ} \mathrm{C}$. Aún cuando la recuperación del sistema en esta fecha no fue total comparado con abril de 2013, las isopicnas se observaron a menor profundidad y con una pendiente positiva. Con respecto a la salinidad, las observaciones mostraron valores dentro de la norma o ligeramente positivos en los primeros $100 \mathrm{~m}$ de profundidad, pero persistieron las anomalías negativas (aunque de menor magnitud) debajo de los $100 \mathrm{~m}$.

\section{DisCUSIÓN}

En este trabajo se mostraron los efectos de la secuencia de los eventos La Mancha y El Niño sobre la hidrografía frente a la costa noroeste de la península de Baja California, México, utilizando datos recolectados por cruceros de oportunidad en la bahía Todos Santos y a lo largo de la línea 100 del programa IMECOCAL. En la bahía, los datos de primavera mostraron diferencias importantes en la respuesta hidrográfica ante los forzamientos interanuales respecto a los datos de Septiembre. Para las campañas de marzo, la curva T-S promedio con las salinidades más bajas correspondió a datos obtenidos durante un evento frío de La Niña en 2011. Las bajas salinidades parecen estar asociadas a una intensificación en el transporte de agua de origen subártico por la corriente de California, como se ha documentado para otras regiones del Sistema de la Corriente de California (Bjorkstedt et al. 2011). Por otro lado, las máximas salinidades estuvieron asociadas al calentamiento anómalo debido a La Mancha. Los factores que pudieron haber generado un aumento de salinidad durante este evento son la advección anómala de aguas de origen tropical y subtropical asociada con flujos costeros hacia el polo, y una mayor tasa de evaporación en la interfase. Aunque no se cuenta con los elementos suficientes para evaluar la importancia relativa de este último, estudios previos (e.g., Zaba y Rudnick 2016) mostraron que, a nivel regional del Sistema de la Corriente de California, el amento en la salinidad se debió, en parte, a la modificación de las tasas de intercambio aire-mar y al debilitamiento de los vientos. El presente trabajo evaluó la posibilidad de la existencia de flujos costeros hacia el polo con base en datos del nivel del mar.

Los efectos de los eventos cálidos La Mancha y El Niño en la temperatura promedio de la parte superior de la columna de agua $\left(\sigma_{\theta}<26 \mathrm{~kg} \cdot \mathrm{m}^{-3}\right)$ sólo se hicieron evidentes durante septiembre de cada año, pero no en marzo. Esta diferencia sugiere que durante la primavera (marzo), los afloramientos costeros pudieran ser más importantes que los 
The effects of the Blob and El Niño warm events on average temperature in the upper layer of the water column $\left(\sigma_{\theta}<26 \mathrm{~kg} \cdot \mathrm{m}^{-3}\right)$ became evident only in September of all years, not in March. This difference suggests that in spring, coastal upwelling may be more important than the effects of remote signal propagations. With stronger, more persistent winds during spring, remote signals can be masked by local forcings and reduce the effects on hydrography at a broader timescale, as noted in the bay. This also seemed to be the case for the outer part of the bay during spring 2016, given the rapid recovery of the system as of January. This observation is consistent with observations recorded off California (Gentemann et al. 2017) and with the results of numerical models that attribute the initial forcing of a warm event to the propagation of signals from the equator and the decline of the event to the relative influence of local forcings (Frischknecht et al. 2017). Remote forcings exerted considerable influence on hydrography in September. During this time of the year, although winds promote upwelling, they are less intense and upwelling rates are lower than in spring. Therefore, under these conditions, the combination of processes (weak alongshore winds, remote signals) can uphold the observed anomalies, as suggested by Frischknecht et al. (2017), so that remote oceanic forcing prevails over local effects.

The data on temperature and salinity anomalies in the upper $300 \mathrm{~m}$ along line 100 (Fig. 3) indicated that the succession of events from The Blob to El Niño prompted major effects. This succession was unusual since anomalous abnormal conditions preceded El Niño due to the warming in the northeastern Pacific region. This sequence of events prompted considerable changes at 100-150 m depth, especially in September 2015, when positive temperature anomalies of up to $5{ }^{\circ} \mathrm{C}$ were observed along with the deepening of the California Current core-typically located between 30 and $50 \mathrm{~m}$ depth (Durazo 2015)-to between 100 and $150 \mathrm{~m}$ depth. This deepening occurred because the relatively cold California Current $\left(\sigma_{\theta} \sim 25.4 \mathrm{~kg} \cdot \mathrm{m}^{-3}\right)$ seeks an isopycnal balance below warmer and less dense water. The peak anomalies observed in September 2015 are consistent with the maximum anomaly reported for southern California based on the analysis of satellite images of sea surface temperature (Gentemann et al. 2017).

The presence of water with higher temperature and salinity during the Blob and El Niño could have resulted from the advection of tropical and subtropical waters. To further explore this hypothesis, anomalies of sea surface absolute dynamic topography for September 2013, 2014 and 2015 were calculated relative to the long-term monthly climatological mean (1992-2016) (Fig. 4). In accordance with the average $\mathrm{T}-\mathrm{S}$ curves and the anomalous hydrographic conditions described above, maps of anomalies and geostrophic currents associated with spatial gradients of sea level revealed that conditions were nearly average in September 2013 (Fig. 4a). However, in September 2014 (Fig. 4b), anomalies become efectos de la propagación de señales remotas. Con vientos de mayor intensidad y persistencia durante la primavera, las señales remotas pueden enmascararse por los forzamientos locales y reducir los efectos de mayor escala temporal sobre la hidrografía, como se observó en la bahía. Este también pareció ser el caso fuera de la bahía durante la primavera de 2016, dada la pronta recuperación del sistema a partir de enero. Esta observación es consistente con los resultados de modelos numéricos que atribuyen la propagación de señales desde el ecuador como el forzamiento inicial de un evento cálido, y la influencia de procesos locales en su posterior decaimiento (Frischknecht et al. 2017); además, es consistente con observaciones hechas para la zona frente a California (Gentemann et al. 2017). En septiembre, la influencia de forzamientos remotos sobre la hidrografía fue muy notoria. En esta época, aunque los vientos son favorables a la surgencia, estos son de menor intensidad y las tasas de afloramiento son menores, en comparación con la primavera. Por tanto, es posible que bajo estas condiciones la combinación de procesos (e.g., vientos débiles, señales remotas) puede originar una retroalimentación en las anomalías observadas, como lo sugieren Frischknecht et al. (2017), de tal forma que el forzamiento oceánico remoto domine sobre los efectos locales.

Los datos de anomalías de temperatura y salinidad de los primeros $300 \mathrm{~m}$ en la línea 100 (Fig. 3) indicaron que la sucesión de eventos de La Mancha hacia El Niño produjeron efectos muy importantes. Esta sucesión fue inusual ya que las condiciones previas al evento El Niño fueron anómalas debido al calentamiento en la región del Pacífico nororiental. Este orden de eventos originó cambios importantes en los primeros 100-150 m de profundidad, sobre todo en septiembre de 2015, cuando se observaron anomalías positivas de temperatura de hasta $5{ }^{\circ} \mathrm{C}$ y el núcleo de la corriente de California, que normalmente se encuentra entre los 30 y $50 \mathrm{~m}$ (Durazo 2015), se ubicó a profundidades de entre 100 y 150 m. Esta profundización ocurrió debido a que el agua relativamente fría de la corriente de California $\left(\sigma_{\theta} \sim 25.4 \mathrm{~kg} \cdot \mathrm{m}^{-3}\right)$ busca su equilibrio isopicnal debajo de aguas de mayor temperatura y menor densidad. El máximo en las anomalías observado en septiembre de 2015 coincide con el máximo reportado para el sur de California a partir del análisis de imágenes de satélite de temperatura superficial del océano (Gentemann et al. 2017).

La presencia de aguas de mayor temperatura y salinidad durante La Mancha y El Niño pudo deberse a procesos de advección de aguas tropicales y subtropicales. Para profundizar sobre esta hipótesis, se analizaron los datos de anomalías de la topografía dinámica absoluta de la superficie del mar durante septiembre de 2013, 2014 y 2015, referidas a la media climatológica mensual de largo período (1992-2016) (Fig. 4). Consistentes con las curvas promedio T-S y con las condiciones hidrográficas anómalas mostradas anteriormente, los mapas de anomalías y las corrientes geostróficas asociadas con los gradientes espaciales del nivel del mar 

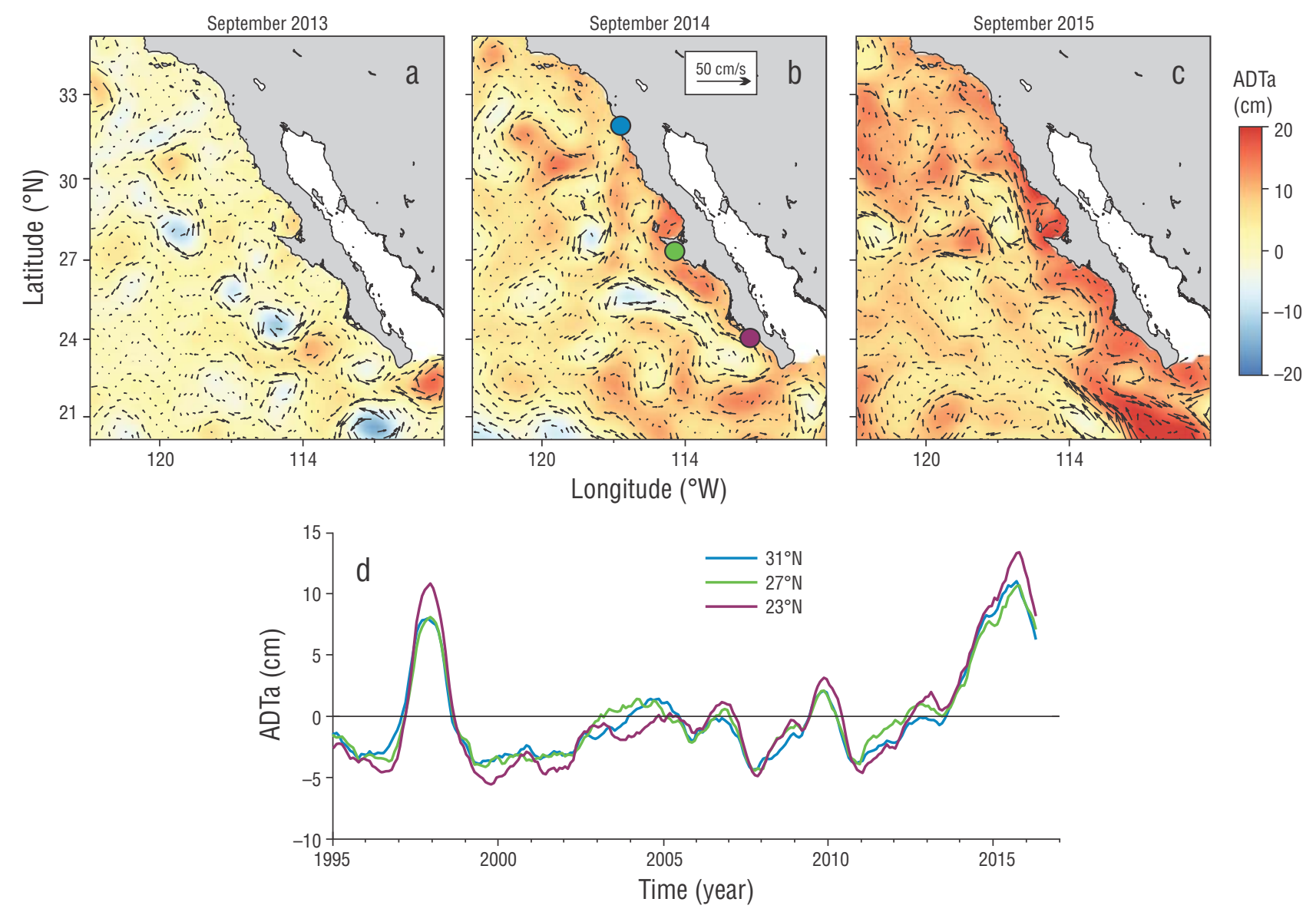

Figure 4. Maps of absolute dynamic topography anomaly (ADTa, cm) for September 2013 (a), 2014 (b), and 2015 (c). Vectors indicate geostrophic currents associated with horizontal sea level gradients. (d) Temporal variation of the average anomaly (cm) in the 3 coastal regions indicated as colored circles in $(\mathbf{b})$.

Figura 4. Mapas de anomalía de altura dinámica absoluta (ADTa, cm) para septiembre de 2013 (a), 2014 (b) y 2015 (c). Los vectores indican las corrientes geostróficas asociadas con los gradientes horizontales de la altura del nivel del mar. (d) Variación temporal de la anomalía promedio $(\mathrm{cm})$ en las 3 regiones costeras indicadas con círculos de color en $(\mathbf{b})$.

positive throughout the region off Baja California, particularly in the coastal region. This was even more evident in September 2015 (Fig. 4c). The existence of peak positive anomalies near the coast implies a positive (west-east) slope at the surface, suggesting a geostrophic surface poleward current along the coast. This is clearly marked by the geostrophic current vectors superimposed on anomaly maps for September 2014 and 2015, and reveals that advection of tropical waters occurred in 2014 and 2015 as a surface countercurrent that influenced the hydrographic conditions observed in the study area. This pattern is very similar to the spatial field of the first mode of empirical orthogonal functions that reproduces the interannual variability, which was applied to the monthly maps of absolute dynamic topography anomalies (not shown).

It is important to analyze not only the spatial distribution of anomalies that allows understanding of coastal dynamics, but also the temporal evolution. To summarize this analysis, the temporal evolution of the dynamic topography anomaly muestran que durante septiembre de 2013 las condiciones estuvieron alrededor del promedio (Fig. 4a). Sin embargo, para septiembre de 2014 (Fig. 4b), las anomalías se volvieron positivas en toda la región frente a Baja California, particularmente en la región costera. Esto fue aún más acentuado en septiembre de 2015 (Fig. 4c). La existencia de anomalías positivas máximas cercanas a la costa implica una pendiente positiva de la superficie (oeste-este), y sugiere una corriente geostrófica superficial dirigida hacia el polo a lo largo de la costa. Esta corriente está claramente indicada por los vectores de corrientes geostróficas sobrepuestos en los mapas de anomalías para septiembre de 2014 y 2015, y muestra que la advección de aguas de origen tropical ocurrió en 2014 y 2015 como una contracorriente superficial que contribuyó a modificar las condiciones hidrográficas observadas en la zona de estudio. Este patrón es muy similar al campo espacial del primer modo de funciones empíricas ortogonales que reproduce la variabilidad interanual aplicado a los mapas mensuales de anomalías de topografía dinámica absoluta (no mostrado). 
was examined in 3 coastal regions along the coast of the Baja California peninsula, at $24^{\circ} \mathrm{N}, 28^{\circ} \mathrm{N}$ and $32^{\circ} \mathrm{N}$ (Fig. $4 \mathrm{~d}$ ). These latitudes coincide more or less with the eastern end of 3 IMECOCAL cardinal lines, namely lines 150, 120 and 100, respectively (Fig. 4b). For each region of approximately $80 \times 80 \mathrm{~km}$, the average absolute dynamic topography anomaly was obtained with a monthly temporal resolution. The temporal evolution in the 3 sites is spatially consistent, since sea surface varies in phase at the 3 locations in response to interannual events. In general, sea surface topography shows larger anomalies to the south $\left(24^{\circ} \mathrm{N}\right)$ relative to the central and northern regions of the peninsula. Other important aspects also emerged from these time series. The negative anomalies observed in 1999-2003, 2008 and 2011 are indicative of La Niña events and imply a greater offshore Ekman transport and a higher coastal upwelling rate. Positive anomalies indicate warm events. During El Niño 1997-1998, the coastal ocean responded with a sea level rise of about $10 \mathrm{~cm}$ above the climatological mean, while in other El Niño events, such as the 2007 and 2010 events, sea-level rise was relatively modest $(\sim 2 \mathrm{~cm})$. The maximum magnitude of these anomalies $(\sim 12-14 \mathrm{~cm})$ occurred during the succession from the Blob to El Niño. This peak was the culmination of a process that started in 2011 as a recovery from La Niña, and the anomalous warming that lasted until the winter of 2015-2016.

In summary, positive coastal anomalies resulting from warm events promote a positive zonal slope that implies a near surface poleward coastal countercurrent and the advection of tropical and subtropical waters, which in turn influence the hydrographic conditions in the northwestern coastal region of the Baja California Peninsula. These coastal flows are expected to intensify under extreme conditions such as observed in 1997-1998 or in the succession of warm events between 2013 and 2016. At the local level (i.e., in Todos Santos Bay) the local forcings seem to play a key role, at least during the upwelling season, by masking the contributions of the interannual pulses. The effects of this type of local variability and adaptability to the various trophic levels of the ecosystem merit further research.

\section{ACKNOWLEDGMENTS}

The authors acknowledge the learnings and guidance of Gilberto Gaxiola-Castro ${ }^{\dagger}$ (RIP), who was the cornerstone and leader of the IMECOCAL program since its foundation. We are grateful to The National Council for Science and Technology (Mexico) for funding this work through projects 23804, 255602, and 254745. Thanks are also due to the Mexican Army for facilitating vessels for the course field trips with students and to CICESE for granting preferential ship time rates for the IMECOCAL program and especially for financing ship time for cruise 1601. Participation of students from the Faculty of Marine Sciences at UABC during fieldwork was key to achieving the objectives of this work.
Es importante analizar no sólo las distribuciones espaciales de anomalías que permiten razonar sobre la dinámica costera, sino también su evolución temporal. Para sintetizar este análisis, se examinó la evolución temporal de la anomalía de topografía dinámica en 3 regiones costeras a lo largo de la península de Baja California, en latitudes de $24^{\circ} \mathrm{N}, 28^{\circ} \mathrm{N}$ y $32^{\circ} \mathrm{N}$ (Fig. 4d); estas latitudes coinciden aproximadamente con el extremo oriental de 3 líneas cardinales de IMECOCAL, las líneas 150, 120 y 100, respectivamente (Fig. 4b). Para cada región de aproximadamente $80 \times 80 \mathrm{~km}$, se obtuvo el promedio de la anomalía de topografía dinámica absoluta con una resolución temporal mensual. La evolución temporal en los 3 sitios mostró coherencia espacial, ya que en las 3 localidades la superficie del mar varió en fase ante eventos de escala interanual. De forma general, la superficie del mar presenta anomalías de mayor magnitud en la región sur $\left(24^{\circ} \mathrm{N}\right)$ con relación a la región central y norte de la península. De estas series de tiempo destacan también algunos aspectos importantes. Las anomalías negativas en 1999-2003, 2008 y 2011 indican eventos La Niña e implican mayor transporte de Ekman hacia afuera de la costa y mayor tasa de afloramiento costero. Las anomalías positivas señalan los eventos cálidos. Durante el evento El Niño 1997-1998, el océano costero respondió con elevaciones de la superficie del mar de unos $10 \mathrm{~cm}$ por encima de la media climatológica, mientras que durante otros eventos El Niño, como el de 2007 y el de 2010, la elevación fue de menor magnitud $(\sim 2 \mathrm{~cm})$. La magnitud máxima de anomalías $(\sim 12-14 \mathrm{~cm})$ ocurrió durante la sucesión de La Mancha hacia El Niño. Este máximo fue la culminación de un proceso que inició en 2011 como un periodo de recuperación desde La Niña, y el calentamiento anómalo que perduró hasta el invierno 2015-2016.

En resumen, las anomalías costeras positivas producto de eventos cálidos favorecen una pendiente zonal positiva que implica una contracorriente costera hacia el polo y la advección de aguas de origen tropical y subtropical. Estos procesos modifican a su vez las condiciones hidrográficas en la región costera frente al noroeste de la península de Baja California. Es de esperar que estos flujos costeros se intensifiquen bajo condiciones extremas como las que ocurrieron en 1997-1998, o como en la sucesión de eventos cálidos entre 2013 y 2016. A nivel local (i.e., en la bahía Todos Santos), los forzamientos locales parecen jugar un papel relevante, al menos durante la época de surgencias, al enmascarar las contribuciones de los pulsos interanuales. Los efectos de este tipo de variabilidad y adaptabilidad local hacia los diferentes niveles tróficos del ecosistema quedan todavía por investigarse.

\section{Agradecimientos}

Los autores reconocen las enseñanzas y guía de Gilberto Gaxiola-Castro $^{\dagger}$ (QEPD), quien fue pilar y motor del programa IMECOCAL desde su fundación. Agradecemos al 
$\mathrm{RD}, \mathrm{RC}$ and FDH hold grants from the National System of Researchers. María Elena Sánchez-Salazar translated the manuscript into English.

\section{REFERENCES}

Bjorkstedt EP, Goericke R, Mcclatchie S, Weber E, Watson W, Lo N, Peterson B, Emmett B, Brodeur R, Peterson J, et al. 2011. State of the California current 2010-2011: Regionally variable responses to a strong (but fleeting?) La Niña. CalCOFI Rep. 52: 36-68.

Bond NA, Cronin MF, Freeland H, Mantua N. 2015. Causes and impacts of the 2014 warm anomaly in the NE Pacific. Geophys. Res. Lett. 42: 3414-3420.

http://dx.doi.org/10.1002/2015GL063306

Cavole LM, Demko AM, Diner RE, Giddings A, Koester I, Pagniello CMLS, Paulsen ML, Ramirez-Valdez A, Schwenck SM, Yen NK, Zill ME, Franks PJS. 2016. Biological impacts of the 2013-2015 warm-water anomaly in the Northeast Pacific: Winners, losers, and the future. Oceanography 29(2): 273-285. http://dx.doi.org/10.5670/oceanog.2016.32

Durazo R. 2009. Climate and upper ocean variability off Baja California, Mexico: 1997-2008. Prog. Oceanogr. 83: 361-368. http://dx.doi.org/10.1016/j.pocean.2009.07.043

Durazo R. 2015. Seasonality of the transitional region of the California Current System off Baja California. J. Geophys. Res. Ocean. 120(2): 1173-1196. http://dx.doi.org/10.1002/2014JC010405

Durazo R, Baumgartner TR. 2002. Evolution of oceanographic conditions off Baja California: 1997-1999. Prog. Oceanogr. 54: 7-31.

Emery WJ, Thomson RE. 2001. Data analysis methods in physical oceanography. Elsevier.

Espinosa-Carreon TL, Strub PT, Beier E, Ocampo-Torres F, Gaxiola-Castro G. 2004. Seasonal and interannual variability of satellite-derived chlorophyll pigment, surface height, and temperature off Baja California. J. Geophys. Res. 109(C3): C03039. http://dx.doi.org/10.1029/2003JC002105

Frischknecht M, Münnich M, Gruber N. 2017. Local atmospheric forcing driving an unexpected California Current System response during the 2015-2016 El Niño. Geophys. Res. Lett. 44(1): 304-311. http://dx.doi.org/10.1002/2016GL071316

Gaxiola-Castro G, Durazo R, Lavaniegos B, De La Cruz-Orozco ME, Millan-Nuñez E, Soto-Mardones L, Cepeda-Morales J. 2008. Pelagic ecosystem response to interannual variability off Baja California $=$ Respuesta del ecosistema pelágico a la variabilidad interanual del océano frente a Baja California. Cienc. Mar. 34(2): 263-270.
Consejo Nacional de Ciencia y Tecnología (México) el financiamiento de las observaciones a través de los proyectos no. 23804, 255602 y 254745 . Así mismo, estamos agradecidos con la Armada de México por facilitar buques para la realización de prácticas estudiantiles y con el CICESE por otorgar tarifas de tiempo de barco preferenciales para el programa IMECOCAL y, en especial, por financiar el tiempo de barco del crucero 1601. La participación de los estudiantes de la Facultad de Ciencias Marinas de la UABC en las prácticas de campo fue crucial para lograr los objetivos de este manuscrito. RD, RC y FDH son receptores de beca del Sistema Nacional de Investigadores.

Gentemann CL, Fewings MR, García-Reyes M. 2017. Satellite sea surface temperatures along the West Coast of the United States during the 2014-2016 northeast Pacific marine heat wave. Geophys. Res. Lett. 44(1): 312-319. http://dx.doi.org/10.1002/2016GL071039

Gómez-Ocampo E, Gaxiola-Castro G, Durazo R, Beier E. 2017. Effects of the 2013-2016 warm anomalies on the California Current phytoplankton. Deep Sea Res. Part II Top. Stud. Oceanogr. http://dx.doi.org/10.1016/j.dsr2.2017.01.005

Jacox MG, Hazen EL, Zaba KD, Rudnick DL, Edwards CA, Moore AM, Bograd SJ. 2016. Impacts of the 2015-2016 El Niño on the California Current System: Early assessment and comparison to past events. Geophys. Res. Lett. 43(13): 7072-7080. http://dx.doi.org/10.1002/2016GL069716

Leising AW, Schroeder ID, Bograd SJ, Abell J, Durazo R, CaxiolaCastro G, Bjorkstedt EP, Field J, Sakuma K, Robertson RR, et al. 2015. State of the California Current 2014-15: Impacts of the warm-water "Blob." CalCOFI Rep. 56: 31-68.

Linacre L. 2004. Community structure of euphausiids in the southern part of the California Current during October 1997 (El Niño) and October 1999 (La Niña). CalCOFI Rep. 45: 126-135.

McClatchie S, Goericke R, Leising A, Auth T, Bjorkstedt E, Robertson R, Brodeour R, Du X, Daly E, Morgan C, et al. 2016. State of the California Current 2015-16: comparisons with the 1997-98 El Niño. CalCOFI Rep. 57: 5-61.

Zaba KD, Rudnick DL. 2016. The 2014-2015 warming anomaly in the Southern California Current System observed by underwater gliders. Geophys. Res. Lett. 43(3): 1241-1248. http://dx.doi.org/10.1002/2015GL067550

Received March 2017, accepted May 2017. 